\title{
The relationships between soil chemical properties and vegetation succession in the aspect of changes of distance from the glacier forehead and time elapsed after glacier retreat in the Irenebreen foreland (NW Svalbard)
}

\author{
Paulina Wietrzyk (D) $\cdot$ Kaja Rola $\cdot$ Piotr Osyczka • \\ Pawel Nicia • Wojciech Szymański • Michał Wegrzyn \\ Received: 15 January 2018 / Accepted: 18 April 2018/Published online: 7 May 2018 \\ (C) The Author(s) 2018
}

\begin{abstract}
Aims The aim of this study was to determine relationships between soil chemical parameters (i.e. content of total organic carbon, total nitrogen, total sulphur, soil
\end{abstract}

Responsible Editor: Zucong Cai.

Electronic supplementary material The online version of this article (https://doi.org/10.1007/s11104-018-3660-3) contains supplementary material, which is available to authorized users.

P. Wietrzyk $(\bowtie) \cdot$ P. Osyczka $\cdot$ M. Wegrzyn

Professor Z. Czeppe Department of Polar Research and

Documentation, Institute of Botany, Jagiellonian University,

Gronostajowa 3, 30-387 Cracow, Poland

e-mail: paulina.wietrzyk@ doctoral.uj.edu.pl

P. Osyczka

e-mail: piotr.osyczka@uj.edu.pl

M. Węgrzyn

e-mail: michal.wegrzyn@uj.edu.pl

K. Rola

Department of Plant Ecology, Institute of Botany, Jagiellonian University, Gronostajowa 3, 30-387 Cracow, Poland

e-mail: kaja.skubala@uj.edu.pl

P. Nicia

Department of Soil Science and Soil Protection, University of Agriculture in Krakow, Mickiewicza 21, 31-120 Cracow, Poland e-mail: rrnicia@cyf-kr.edu.pl

W. Szymański

Department of Pedology and Soil Geography, Institute of Geography and Spatial Management, Jagiellonian University, Gronostajowa 7, 30-387 Cracow, Poland e-mail: w.szymanski@uj.edu.pl
$\mathrm{pH})$ and vegetation development in relation to distance from the current glacier forehead and time elapsed after glacier retreat in the Irenebreen foreland.

Methods Three transects were designated along the foreland. Species and vegetation cover were investigated in $1 \mathrm{~m}^{2}$ plots, placed every $50 \mathrm{~m}$ along each transect; corresponding soil samples were collected and chemically analysed.

Results The total organic carbon and total nitrogen contents in soil change according to power and exponential functions, respectively, whereas soil $\mathrm{pH}$ decreases linearly with increased time elapsed after glacier retreat. The wide variation in total sulphur contents prevent the determination of clear relationships. Bryophytes and vascular plants dominate in the younger part of the foreland, whereas epigeic lichens prevail in the older part.

Conclusions Vegetation cover seems to be the main factor effects on soil properties; however, chemical soil properties and distance from the glacier forehead affect species distribution and vegetation cover. Considered so far as the first pioneers, the epigeic lichens need more time than bryophytes and vascular plants to colonise the foreland.

Keywords Arctic C Carbon - Cryptogamic species · Nitrogen · Sulphur · Tundra soils

\section{Introduction}

The Arctic is one of the regions most threatened by climate change (Arndt et al. 2010; Hansen et al. 2012; 
IPCC 2007, 2014). Many studies suggest that climate changes may have an important impact on element cycles in the forelands of Arctic glaciers, and thus on the development of vegetation cover during the primary succession (e.g. Oechel and Vourlitis 1994; Wietrzyk et al. 2016; Yoshitake et al. 2011). Documentation of glacier range changes is very broad and includes both polar and mountain regions (Burga et al. 2010; Dai et al. 2002; Dümig et al. 2011; Elberling et al. 2004; Grieve 2000; Kabala and Zapart 2012; Nakatsubo et al. 2005). Studies clearly show a loss of glaciers on all continents, progressing especially in the second half of the twentieth century (Nuth et al. 2013; Zemp et al. 2008). In Svalbard, the progressive recession of glaciers has been observed since the end of the Little Ice Age (Błaszczyk et al. 2009). Glaciers have been reduced in terms of both thickness and area (e.g. James et al. 2012; Kohler et al. 2007; Nuth et al. 2013). Retreating glaciers uncover new land surfaces within postglacial valleys and these freshly deglaciated surfaces are characterised by a lack of biological life, including vegetation cover, whose development is connected with the availability of nutrients and water in soil (Burga et al. 2010). On the other hand, the supply of dead organic matter increases along with vegetation development, which results in increasing carbon accumulation in the soil. Nowadays, the phenomenon of glacier recession affords an opportunity to investigate changes in carbon and nitrogen accumulation in soils developed in forelands from the barren ground in the immediate vicinity of the actual glacier front to the oldest part of the foreland, as well as the interrelated nature of vegetation succession and chemical properties of soils.

In previous studies in the glacier forelands of the High Arctic (Elberling et al. 2004; Kabala and Zapart 2012; Nakatsubo et al. 2005) and in alpine regions (Burga et al. 2010; Dai et al. 2002; Dümig et al. 2011; Grieve 2000), great attention was paid to carbon accumulation and its cycle. Very few studies refer to the relationship between carbon storage and vegetation (e.g. Nakatsubo et al. 2005; Vilmundardóttir et al. 2015; Yoshitake et al. 2011). Apart from carbon, several studies consider nitrogen accumulation in the soil of Arctic glacier forelands (Crocker and Dickson 1957; Hodkinson et al. 2003; Jacobson and Birks 1980; Kabala and Zapart 2012; Yoshitake et al. 2007) and alpine glaciers (Noll and Wellinger 2008). Up to now, total sulphur content has not been studied in the soils of Arctic glacier forelands, despite the fact that sulphur is one of the most important elements taking part in the metabolic processes of plants such as photosynthesis and fixation of nitrogen (Brady and Weil 2004). Moreover, its content in the soil may be responsible for primary vegetation succession in the glacier foreland. Sulphate and sulphur contents have been examined only in the foreland of the Damma Glacier in Switzerland and were positively correlated with the organic carbon distribution (Noll and Wellinger 2008; Prietzel et al. 2013).

In terms of vegetation succession, the most detailed analyses in Svalbard's glacier forelands were associated with studies of vascular plants (e.g. Pirożnikow and Górniak 1992; Prach and Rachlewicz 2012; Yoshitake et al. 2011). Other components of glacier foreland vegetation, in particular cryptogams, have usually been overlooked and have not been identified at the species level. The high number of cryptogamic species colonising freshly deglaciated forelands, considerably exceeds the number of vascular plants species (Wietrzyk et al. 2016, 2017). This indicates the need for comprehensive research including both vascular plants and cryptogamic species in analyses of vegetation development and its relationships with soil properties. In the early twentieth century, the theory of a linear and directional character of primary succession of vegetation had begun to be questioned because besides the time after glacier retreat, local environmental variables had started to be considered as factors affecting vegetation development as well (Walker and Del Moral 2003). Previous research conducted in Svalbard shows that in addition to the activity of glacier rivers (Moreau et al. 2008), distance from the glacier forehead (Wietrzyk et al. 2016) is also an important factor influencing the process of vegetation succession.

The main aim of the present study was to determine how selected chemical properties of the soil, i.e. content of total organic carbon (TOC), total nitrogen (TN), total sulphur (TS), and soil $\mathrm{pH}$, change with (1) distance from the current glacier forehead; (2) time elapsed after glacier retreat; (3) vegetation cover development in the foreland of Irenebreen. The second aim, considering the same problem from another side, was to estimate which factor, i.e. distance from the current glacier forehead, time elapsed after glacier retreat or soil properties, is of stronger impact for succession of vegetation. In addition, relationships between particular species occurrence, distance from the glacier forehead, time elapsed after glacier retreat and soil chemical properties were analysed. We set the following hypotheses: (1) both 
increased distance from the current glacier forehead and time elapsed after deglaciation positively influence TOC, TN, and TS contents in soil and negatively influence soil $\mathrm{pH}$; (2) with regard to the varying rate of the glacier's retreat over time, the relationship between time elapsed after glacier retreat and soil properties is close to being linear; in contrast, the relationship of distance to soil properties is non-linear in character; (3) spontaneous development of vegetation contributes to increased contents of TOC, TN and TS and reduced $\mathrm{pH}$ in the soil developed in the foreland; (4) development of vegetation cover is dependent mainly on the distance from the glacier forehead.

\section{Materials and methods}

Study area

The fieldwork was conducted in the Irenebreen foreland (Fig. 1). The Irenebreen, one of the forelands bordering the Kaffiøyra Plain (Oscar II Land, NW Spitsbergen), is a polythermal valley glacier with an area of $4.1 \mathrm{~km}^{2}$, approximately $4 \mathrm{~km}$ in length and between $1 \mathrm{~km}$ (in its frontal zone) and $1.5 \mathrm{~km}$ (in the eastern section) in width (Sobota 2011, 2014; Sobota and Lankauf 2010; Sobota et al. 2016). The glacier's average retreat rate is $13 \mathrm{~m}$ per year (Sobota and Lankauf 2010). However, the rate of glacier recession is, apparently, not constant, and this process has clearly accelerated since the beginning of the twenty-first century (IPCC 2007, 2014; Sobota et al. 2016). The Irenebreen foreland is approximately $1700 \mathrm{~m}$ wide and $1200 \mathrm{~m}$ long (Fig. 2). The southern part of the foreland is relatively flat and covered by proglacial river sediments. In contrast, the northern part is characterised by hilly relief. The Irenebreen foreland consists of a series of Vendian rocks known as the Hecla Hoek formation, which also comprises the peak parts of the mountains surrounding the Kaffiøyra glaciers. The Hecla Hoek formation consists mainly of quartzite, phyllite, diamictite, marble, and green slate. Furthermore, the mountains east of the Kaffiøyra Plain consist of thick tilloids, phyllites with frequent intercalations of marble, green phyllites, and occasional metabasic rocks (metadiabase and metagabbro) (Sobota and Lankauf 2010). The immediate vicinity of the Irenebreen is composed of the Comfortlessbreen diamictite formation of Cryogenian and/or Ediacaran age.
The climate of the Kaffiøyra Plain is affected by the West Spitsbergen Current. Summer mean air temperature reaches $4.6{ }^{\circ} \mathrm{C}$; the mean annual air temperature is $-5.8^{\circ} \mathrm{C}$. January is the coldest month, while July is the warmest (mean monthly air temperature: $-14.2{ }^{\circ} \mathrm{C}$ and $4.9^{\circ} \mathrm{C}$, respectively). Cloud cover, which averages more than $70 \%$ in summer and autumn, is lower in winter and spring, affecting the number of hours of sunshine, which in April and May reaches $250 \mathrm{~h}$. In the Kaffiøyra region during the summer months, mean air humidity is $89 \%$ and mean precipitation amounts to $51 \mathrm{~mm}$ (Przybylak and Araźny 2006). The vegetation which surrounds the Irenebreen and its foreland belongs to the alliance Luzulion arcticae Gjærev. 1950 and is composed mainly of the following species: Cerastium arcticum, Salix polaris, Saxifraga cernua, S. cespitosa, S. oppositifolia, Brachythecium glaciale, Polytrichastrum alpinum, Cetrariella delisei, Ochrolechia frigida, Cetraria islandica (Wegrzyn and Wietrzyk 2015). In the Irenebreen foreland, vegetation is mainly represented by initial stages of plant communities in which lichens and bryophytes are the dominant organisms.

\section{Data sampling}

Fieldwork was carried out in summer 2012. The study design included investigation along transects from the current glacier forehead to the terminal moraine. Preliminary fieldwork was carried out across the entire glacier foreland in order to determine the part with the most homogeneous site conditions. Three linear transects, each $1150 \mathrm{~m}$ long, were designated along the foreland. Sampling sites were designated roughly every $50 \mathrm{~m}$ along the transects and included various sites in terms of parent material, geomorphology, and wetness. At each sampling site, overall vegetation cover, including lichen, bryophytes, and vascular plants, was collectively estimated on a percentage scale within a $1 \mathrm{~m}^{2}$ plot, and the percentage cover for each species was determined as well. In the case of taxonomically problematic specimens, samples were collected for precise identification in the laboratory. Simultaneously, soil samples from the surface to a depth of $5 \mathrm{~cm}$ were collected from each sampling site. Consequently, 72 sampling sites in total were taken into account, i.e. 24 per transect (Fig. 1). Moreover, three representative soil profiles were excavated at three different distances (i.e. $0 \mathrm{~m}, 550 \mathrm{~m}$, and $1150 \mathrm{~m}$ ) from the current glacier forehead in order to identify general changes in soil parameters with depth and soil samples from each 


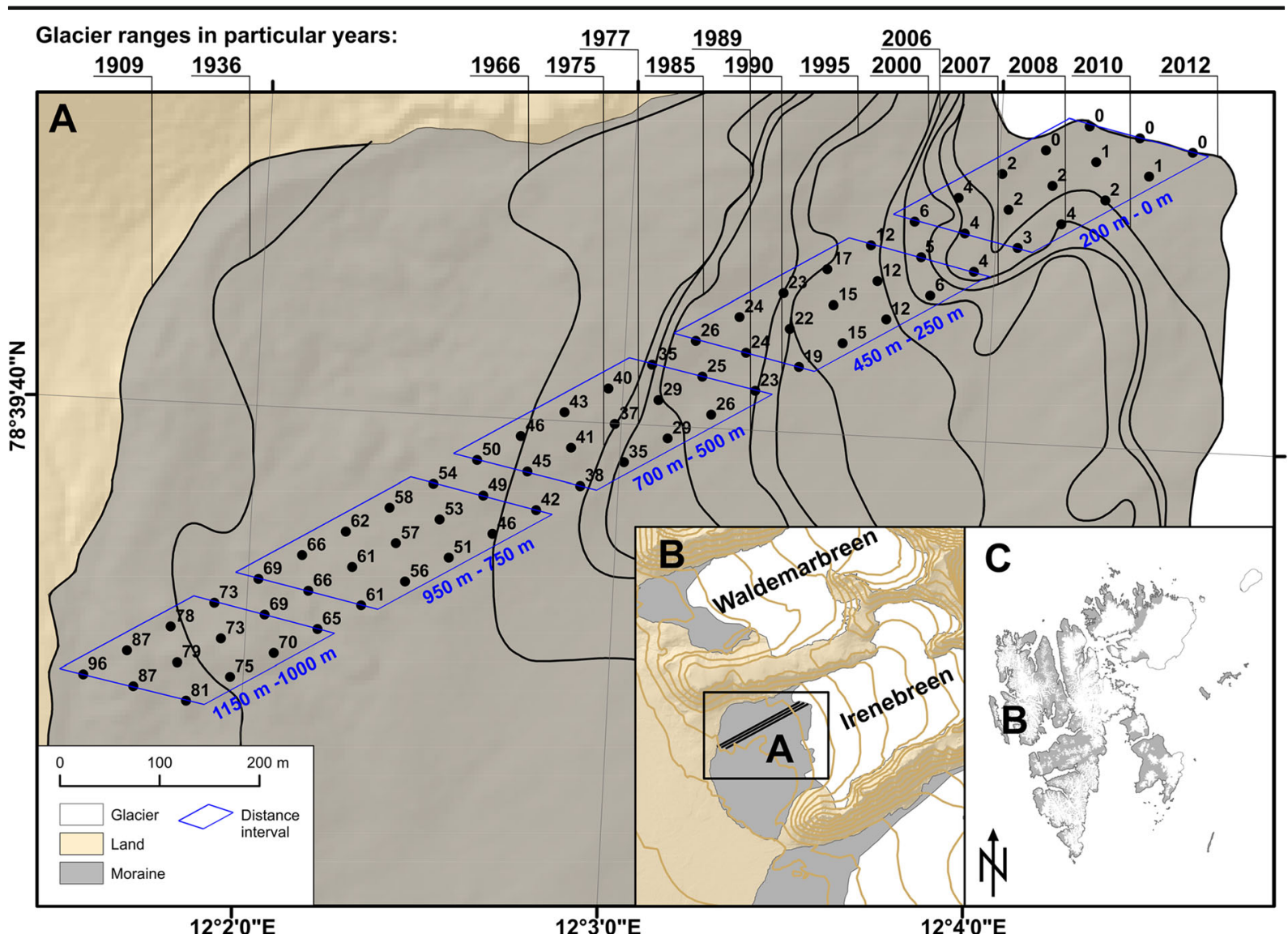

Fig. 1 Location of study area: A - three parallel transects designated along Irenebreen foreland. The points along the three transects mark the sampling sites, the numbers indicate the years after glacier retreat for each of sampling sites and the blue frames

indicate the distance intervals designated along Irenebreen foreland; B - Irenebreen and its foreland; C - Svalbard Archipelago. (C) Norwegian Polar Institute, npolar.no

horizon ( $\mathrm{AC}, \mathrm{Cg} 1, \mathrm{Cg} 2)$ being taken. In addition, the depth of dead-ice occurrence was determined for each profile. The sampling depth differed from profile to profile, depending on the nature of the soil profile.
Glacier ranges in the past and estimated ages of foreland materials in the proglacial zone were assessed based on Sobota and Lankauf (2010). The time period between two different glacier ranges (isochrones) was divided into
Fig. 2 View on Irenebreen foreland from the Gråfjellet Mt (a) and view on Irenebreen forehead from its moraine (b) (Phot. M. Węgrzyn)

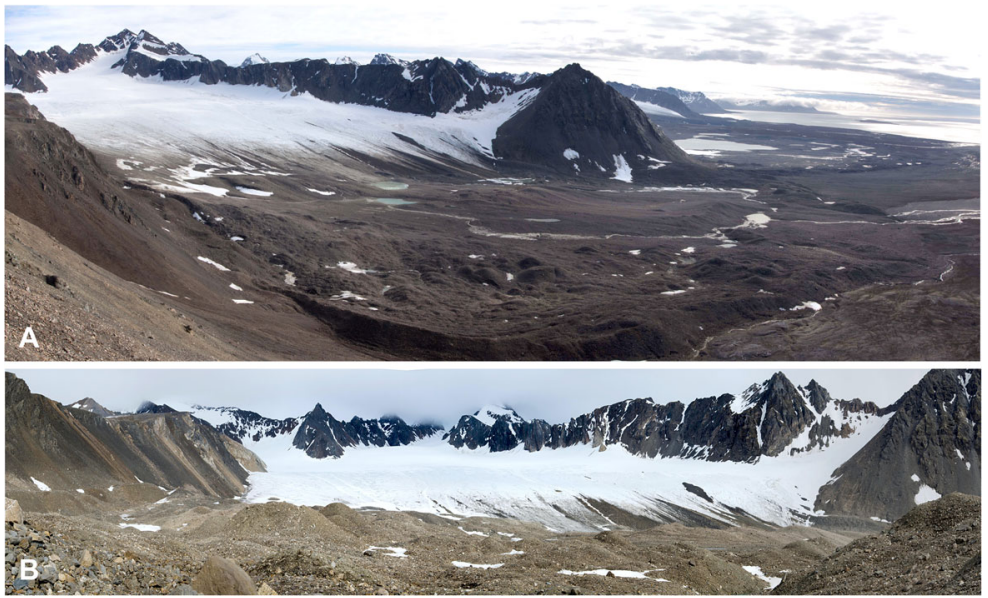


equal parts appropriate for the number of years in each particular time period. Then, a specific age was assigned to given sampling site. This interpolation enabled estimation of the time elapsed since deglaciation for each sampling site.

\section{Soil analyses}

Soil samples were carefully cleaned of plant debris to avoid contamination by organic matter during analysis. The samples were air-dried, gently crushed, and sieved through a 2-mm sieve. All laboratory analyses were done on fine-earth material (fraction $<2 \mathrm{~mm}$ ). Concentrations of TOC, TN, and TS were determined for each soil sample. Previously, all calcareous soil samples had been treated with $10 \% \mathrm{HCl}$ to remove carbonates. Three 1 -g replicates were analysed by means of dry combustion technique using a LECO CNS 2000 automated analyser (LECO 1996), and the mean value was treated as one observation in further analysis. Soil $\mathrm{pH}$ was measured in distilled water in a 1:2.5 $(w / v)$ ratio according to the potentiometric method (Tan 1995) using a pH meter (Elmetron CPI-505) with a glass electrode (Elmetron ERH-11).

\section{Species identification}

Standard light microscopy were used for taxonomic determination of specimens; the following publications were used: Atherton et al. (2010); Brodo et al. (2001); Osyczka and Wegrzyn (2008); Rønning (1996); Smith et al. (2009); and Thomson (1984; 1997). Additionally, chemical analyses of lichen substances were conducted according to the technique of Orange et al. (2001). Herbal materials were deposited in the Herbarium of the Institute of Botany at Jagiellonian University in Kraków (KRA).

\section{Statistical analyses}

Two data matrices were created for statistical analyses. The first, which included data on soil chemical properties and vegetation cover in each analysed plot at a certain distance from the glacier forehead, will be referred to hereafter as the distance data matrix; the second, which included data on soil chemical properties and vegetation cover averaged for particular numbers of years elapsed after glacier retreat, will be referred to hereafter as the time data matrix. First, each sampling site was assigned to one of five distance intervals within each transect based on the geomorphological diversity of the studied moraine (Fig. 1 and S1). The normality of the distribution of the variables TOC, TN, and TS contents and $\mathrm{pH}$ in the distinguished intervals was verified using the Kolmogorov-Smirnov test. Data which did not meet the assumptions of normality were Box-Cox transformed in order to find an optimal normalising transformation. Then, one-way analysis of variance (ANOVA) was performed, followed by Tukey's (HSD) test, to test differences in particular element contents and $\mathrm{pH}$ across the studied intervals. Prior to the analysis, Levene's test was performed to assess the equality of variances.

The relationships between element contents, soil $\mathrm{pH}$, distance from the glacier forehead, time elapsed after glacier retreat, and vegetation cover were calculated separately, using Pearson correlation coefficients for distance matrix and time matrix separately. Next, scatter plots were created for an initial evaluation of the nature of the aforementioned relationships. Subsequently, various functions, i.e. linear, quadratic, power, exponential, logistic, Michaelis, and third- and fourth-degree polynomials, were fitted to the data using LevenbergMarquardt optimisation. The Akaike Information Criterion (AIC) was used to select the best-fitting model. The analyses of relationships between soil parameters and time/distance were performed on the basis of values averaged for the same values of distance and time elapsed after glacier retreat defined for three transects; whereas the analyses of relationships between soil parameters and vegetation cover were performed on two separate data matrices separately.

Cluster analyses of all analysed soil parameters, distance from the glacier forehead, and time elapsed after glacier retreat were carried out using an unweighted pairgroup average (UPGMA) clustering algorithm and Euclidean distance separately for the distance and time matrices.

As regards epigeic vegetation data, canonical correspondence analysis (Legendre and Legendre 1998) was applied to relate the cover of a particular species in the studied plots to soil variables, distance from the glacier forehead and time elapsed after glacier retreat. Data from plots without epigeic vegetation were excluded from the analysis. A forward selection procedure of the explanatory variable from the set of all variables available was applied. A Monte Carlo permutation test (499 permutations) was used in order to assess the statistical significance of relationships between species, environmental factors, and axes (Ter Braak and Šmilauer, 2002). Furthermore, the effect of soil variables, distance from the glacier forehead and time 
elapsed after glacier retreat on the vegetation cover in the studied plots were evaluated by separate stepwise multiple linear regressions using forward variable selection with a threshold of $p<0.05$ to entry. Strongly correlated variables $(R>0.95)$ were removed from the analysis. A detailed residual analysis was performed in order to obtain reliable regression coefficients and detect potential outliers (extreme cases). Finally, a seriation of all species (presence/absence values) recorded in the examined plots, combined for three transects, was performed using an unconstrained algorithm (Brower and Kile 1988).

The analyses were carried out using STATISTICA 12 (Statsoft, Tulsa, OK, USA), PAST 3.10 (Hammer et al. 2001) and CANOCO 4.5 (Ter Braak and Šmilauer, 2002).

\section{Results}

Soil development in the glacier foreland

Along the studied transects, TOC in the surface soil layer increased from a very low content of $0.69 \%$ at the newly exposed sites, which were close to the current edge of the glacier, to $3.81 \%$ in the oldest foreland soils, which were approximately 100 years old; the content of TN increased from $0.04 \%$ to $0.15 \%$. The content of TS was the most diversified along the transects, reaching the lowest values within the first $200 \mathrm{~m}(\sim 0.02 \%)$ and the highest at 750 and $900 \mathrm{~m}(0.09 \%)$. Contrastingly, soil $\mathrm{pH}$ decreased along the transects, ranging from 8.1 in the vicinity of the glacier forehead to 6.3 at the furthest distance from the current glacier position. According to ANOVA, significant differences were found in soil parameters between particular distance intervals (TOC: $\mathrm{F}=164.67$; TN: $\mathrm{F}=97.81$; TS: $\mathrm{F}=9.63$; $\mathrm{pH}$ : $\mathrm{F}=62.65 ; p<0.05$ for all cases). Moreover, the two intervals located furthest from the glacier forehead were characterised by the highest TOC and TN concentrations, in both cases significantly different from the others (Fig. 3a, b). Conversely, soil $\mathrm{pH}$ values were significantly lower in the last two intervals (Fig. 3d). Differences in TS concentration were not as distinct; however, the highest mean TS contents were determined in the last two intervals (Fig. 3c). Cluster analysis of soil parameters and distance from the glacier forehead showed that distance was most strongly associated with TOC content (Fig. S2a), whereas TOC and TN contents were highly correlated with time elapsed after glacier retreat (Fig. S2b).

We found that both TOC and TN contents positively depend on distance from the glacier forehead and time elapsed after glacier retreat (Table 1). Generally, both TOC and TN contents increased with time and distance from the glacier (Figs. 4, S2). Similarly, the content of TS was positively associated with both distance and time; however, the correlation was not as strong (Table 1). Contrastingly, soil $\mathrm{pH}$ decreased significantly with distance and time (Table 1). However, scatter plots provided a basis for believing that at least some of these relationships are non-linear in nature. The best-fitting functions based on AIC values for each relationship are provided in Table S1. Although different types of functions were defined for TOC-distance and TN-distance relationships, the shapes of the curves of these functions were generally similar (Fig. 4a, c). Fitting function graphs indicated that the increases in the contents of these elements with distance were initially slow, but gradually increased (Fig. 4a, c). A similar trend applied to TOC content and time (Fig. 4b). Contrastingly, TN content increased linearly with time elapsed after glacier retreat (Fig. 4d). Linear functions also proved to best fit relationships between TS content and $\mathrm{pH}$ with distance and time (Fig. 4e-h).

Generally, in the studied soil profiles, TOC and TN contents decreased with depth (Table S3). The highest concentrations of these elements were found in surface $\mathrm{AC}$ horizons. The greatest decline was recorded between the AC and $\mathrm{Cg} 1$ horizons, especially at the end of the studied transects (Profile 3). The content of TS was almost evenly distributed throughout all of the studied soil profiles (Table S3). The distinct increase in $\mathrm{pH}$ with depth was noticeable only at the site located furthest from the glacier forehead (Profile 3); however a slight increase in $\mathrm{pH}$ with depth in the soil profile excavated in the middle part of the transect (Profile 2) was also observed (Table S3). The dead-ice layer in the soil profile located at the beginning of the transects started at an approximately $20 \mathrm{~cm}$ depth; in the middle part of transects, dead-ice was recorded at an approximately $35 \mathrm{~cm}$ depth, and at the end of transects at an approximately $45 \mathrm{~cm}$ depth.

Vegetation development in the glacier foreland

In total, 52 species were recorded within the studied plots: 13 species of bryophytes, 30 species of lichens, 

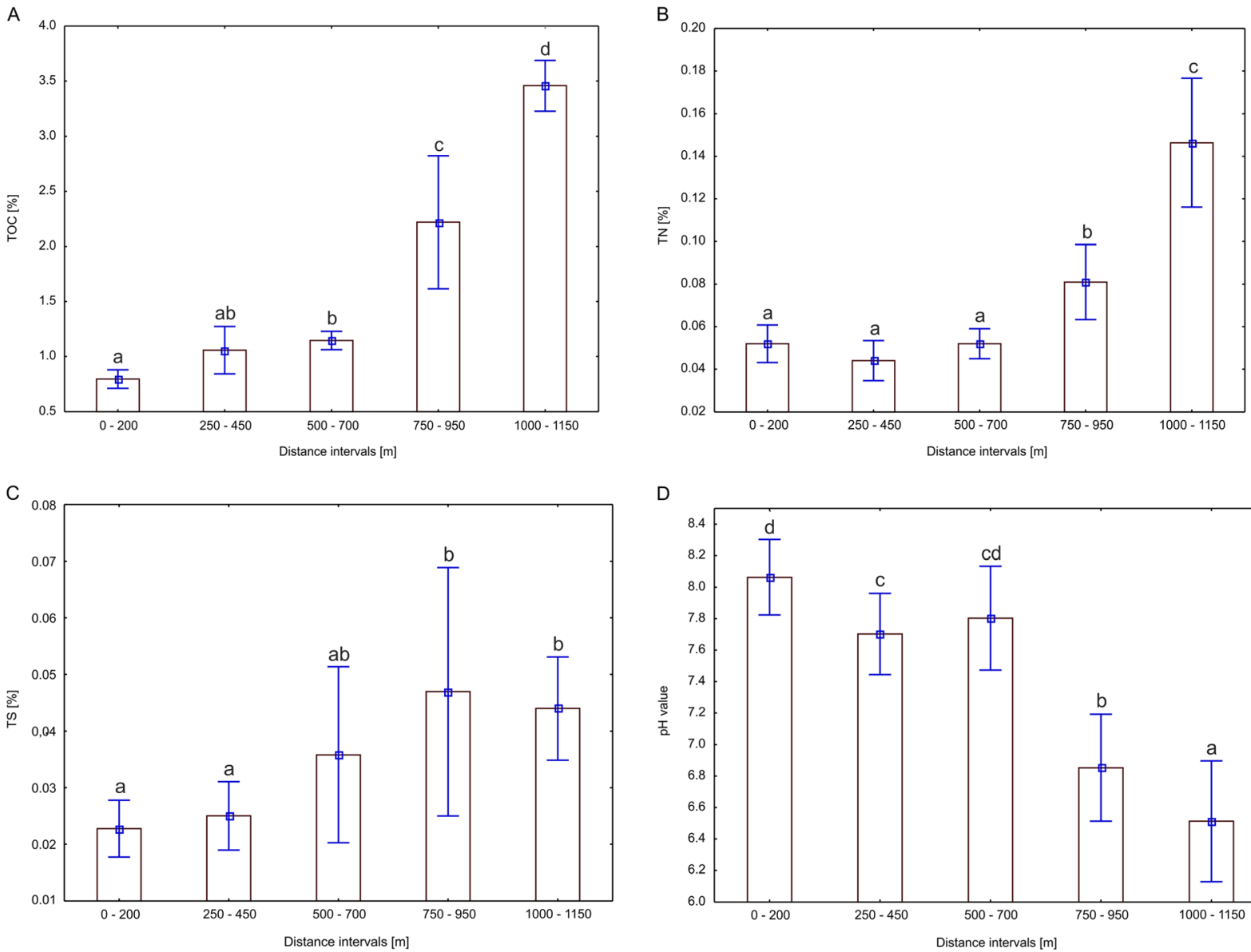

D

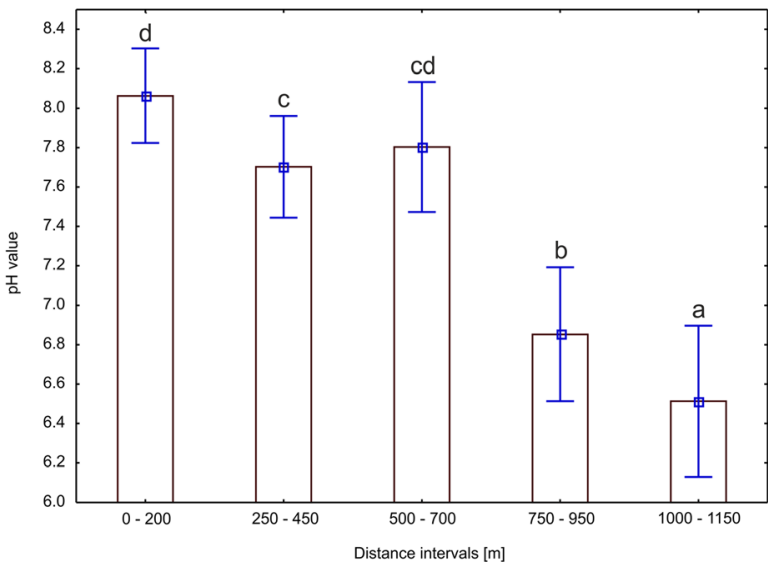

Fig. 3 Total organic carbon - TOC (a), total nitrogen - TN (b), total sulphur - TS (c) contents in surface soil layer and soil pH (d) for particular distance intervals designated along transects. Points

indicate mean values; whiskers indicate standard deviation. Letters denote the results of Tukey's (HSD) test; different letters indicate significant differences at the $p<0.05$ level

Table 1 Pearson's correlation coefficients between soil chemical parameters determined in each sampling site and distance from the glacier forehead (Distance),time elapsed after glacier retreat (Time) and vegetation cover (Veg)

\begin{tabular}{|c|c|c|c|c|c|c|}
\hline Parameter & & TOC & $\mathrm{TN}$ & TS & $\mathrm{pH}$ & Veg \\
\hline \multirow[t]{5}{*}{ Distance matrix } & $\mathrm{TN}$ & $0.880^{* *}$ & - & & & \\
\hline & $\mathrm{TS}$ & $0.508^{*}$ & $0.413^{*}$ & - & & \\
\hline & $\mathrm{pH}$ & $-0.887 * *$ & $-0.763 * *$ & $-0.483 *$ & - & \\
\hline & Veg & $0.816^{* *}$ & $0.663 * *$ & $0.564 *$ & $-0.788 * *$ & - \\
\hline & Distance & $0.884 * *$ & $0.765 * *$ & $0.502 *$ & $-0.869 * *$ & $0.857 * *$ \\
\hline \multirow[t]{5}{*}{ Time matrix } & $\mathrm{TN}$ & $0.894 * *$ & - & & & \\
\hline & $\mathrm{TS}$ & $0.507 * *$ & $0.423 *$ & - & & \\
\hline & $\mathrm{pH}$ & $-0.806 * *$ & $-0.703 * *$ & $-0.450^{*}$ & - & \\
\hline & Veg & $0.684 * *$ & $0.566^{* *}$ & $0.506^{* *}$ & $-0.592 * *$ & - \\
\hline & Time & $0.885 * *$ & $0.804 * *$ & $0.481 *$ & $-0.810^{* *}$ & $0.736^{* *}$ \\
\hline
\end{tabular}

$* P<0.05 ; * * P<0.001$ 

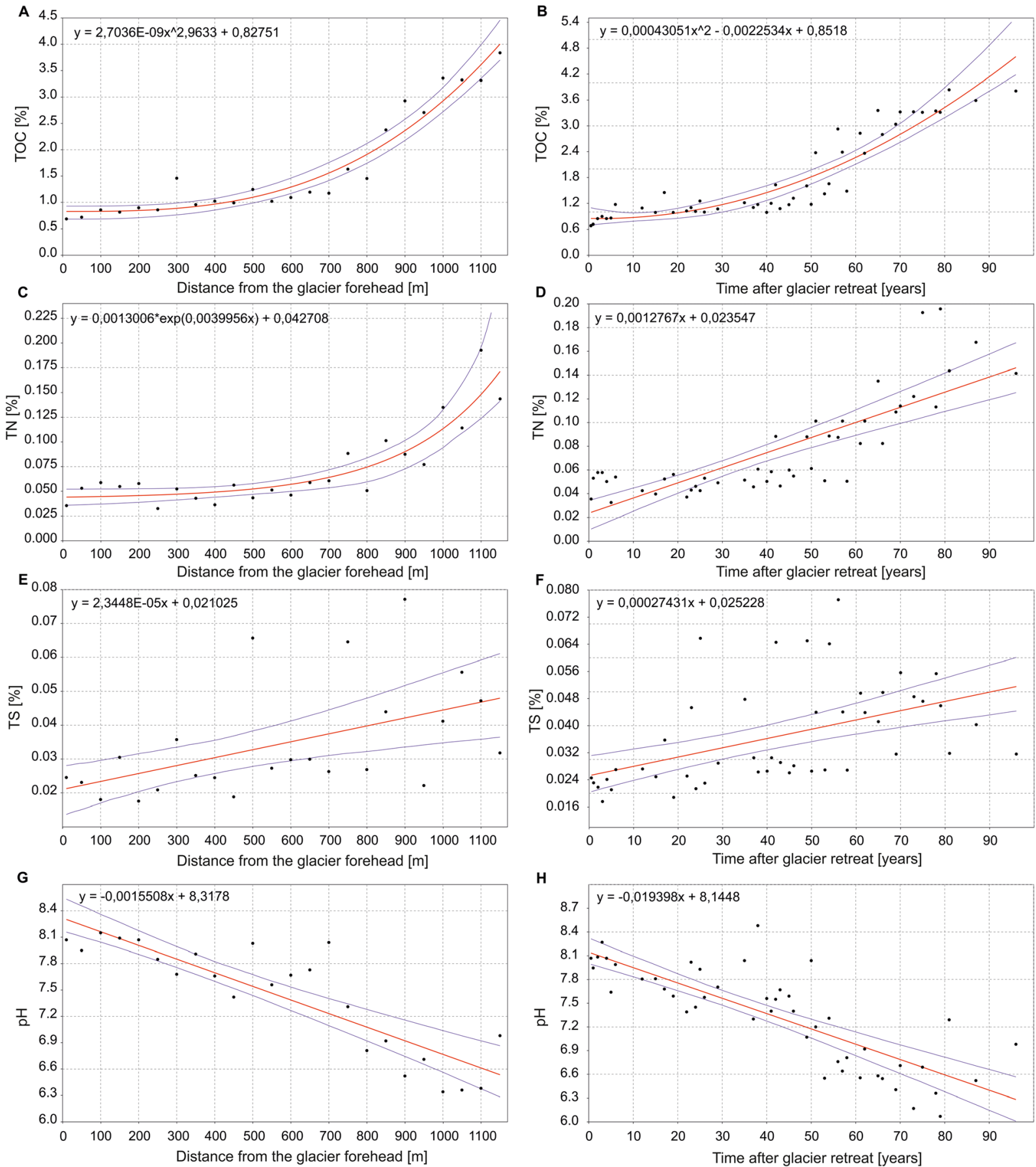

Fig. 4 Relationships between soil properties (TOC, TN, TS, and $\mathrm{pH})$ and the distance from the glacier forehead (a, c, e, g) and relationships between soil properties (TOC, TN, TS, and $\mathrm{pH}$ ) and

time elapsed after glacier retreat $(\mathbf{b}, \mathbf{d}, \mathbf{f}, \mathbf{h})$. Fitted function formulas are presented in the scatterplots

and 9 species of vascular plants (Fig. 7). In the analysis of the occurrence of particular species along the glacier foreland, groups of early and late colonisers may be distinguished: bryophytes, namely Bryum calophyllum 
and Encalypta alpina, were the first species to colonise the freshly deglaciated area, whereas lichens began to occur starting at $350 \mathrm{~m}$ from the glacier forehead and dominated towards the end of the foreland (Fig. 7). Vascular plants were present from a distance of $200 \mathrm{~m}$ from the glacier forehead through the rest of the foreland. The most abundant species of vascular plants were Saxifraga oppositifolia and Cerastium arcticum (Fig. 7). Relationships between species distribution and soil chemical properties, distance from the glacier forehead and time elapsed after glacier retreat were determined using CCA analysis (Fig. 9). The Monte Carlo permutation test showed that both the first axis and all canonical axes taken together were statistically significant ( $p=0.02$ and $p=0.04$, respectively). Cladonia pyxidata, Lecanora epibryon, Lecidea ramulosa, Ochrolechia androgyna, Caloplaca nivalis and Polyblastia sendtneri were associated with high TOC, TN, and TS content. These species were also associated with lower soil $\mathrm{pH}$ and were present in the older part of Irenebreen foreland (Fig. 7). Bryophytes, such as Andreaea blyttii, Bryum pseudotriquetrum, B. turgidum, Ditrichum cylindricum, E. alpina, and Pohlia wahlenbergii exhibited opposite trend (Figs. 7 and 9). Nevertheless, the forward selection procedure of the variables showed that species distribution is associated only with distance from the glacier forehead and TOC content $(\mathrm{F}=3.64 ; p=0.001$ and $\mathrm{F}=2.94 ; p=$ 0.002 , respectively). The obtained results indicated that distance from the glacier forehead and TOC content explained $7.75 \%$ of the overall variability of species occurrence. However, concerning overall vegetation cover, forward stepwise regression analysis with distance from the glacier forehead, time elapsed after glacier retreat and soil variables as predictor variables $(\mathrm{F}=$ $6.51 ; p<0.05)$ showed that vegetation cover was mainly related to four of the analysed factors, i.e. soil $\mathrm{pH}(p=$ $0.027)$, distance from the glacier forehead $(p=0.030)$, content of TOC $(p=0.043)$ and TN $(p=0.024)$. This model explained $38.4 \%$ of the variability of vegetation cover.

Although there were some fluctuations in vegetation cover along the transects (Fig. 9), this parameter was evidently correlated with distance from the glacier forehead and time elapsed after glacier retreat (Table 1). Vegetation cover and soil parameters were also interrelated. Linear functions proved to be the best fitted for relationships between soil parameters and vegetation cover (Table S2). With increasing development of vegetation cover, contents of TOC, TN, and TS gradually increased, whereas $\mathrm{pH}$ decreased; however, the correlations between these parameters were stronger for the distance matrix than for the time matrix (Table 1, Fig. 5).

\section{Discussion}

In this paper, a modified chronosequence method is proposed. This novel approach provides nearcontinuous information on soil development, vegetation succession, and glacier retreat spanning one century. Despite the fact that the distance from the glacier forehead and time elapsed after glacier retreat are correlated, we examined their influence on the development of soil and succession of vegetation separately. Such an approach was applied because the rate of glacier retreat may be not constant over time. Because of that, the model of soil development and vegetation succession in relation to distance and time could be different. This enabled us to identify the nature of these relationships, which is particularly important in the context of the increasing rate of deglaciation process in recent years.

Soil development in the glacier foreland

Soil development is dependent upon various soilforming factors (parent material, topography, climate, biota, and time) and their fluctuations and interferences (Brady and Weil 2004). The obtained results confirmed our first hypothesis assuming that both increased distance from the current glacier forehead and time elapsed after deglaciation positively influence TOC, TN, and TS contents in soil and also they stand in line with our third hypothesis that changes in soil properties are mainly influenced by spontaneous development of vegetation.

The nature of changes in TOC and TN contents is similar, with slow increases at the outset followed by more rapid increases beginning at a distance of $800 \mathrm{~m}$ from the glacier. It was observed that soil development in the glacier forelands significantly accelerates under continuous vegetation cover (Alexander and Burt 1996; He and Tang 2008; Mavris et al. 2010). This may explain the nature of the obtained results, since vegetation cover did not exceed $30 \%$ up to a distance of $700 \mathrm{~m}$ from the glacier forehead, while at greater distances it reached significantly higher values (Figs. 7 and 9). As vegetation succession proceeded, an increase in TOC 

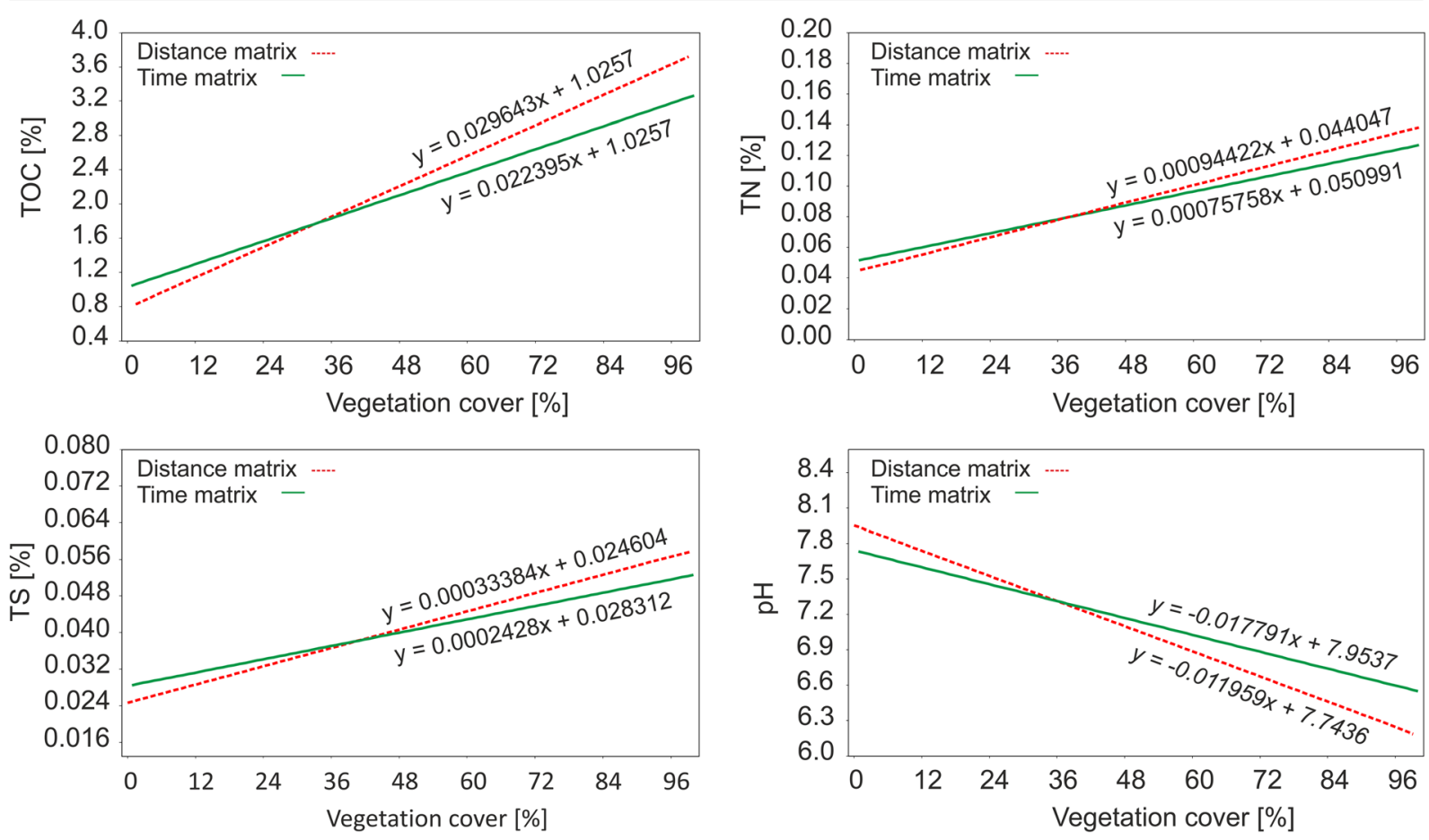

Fig. 5 Relationships between vegetation cover and TOC, TN, TS contents in surface soil layer and soil $\mathrm{pH}$. Combined function graphs were prepared based on analyses performed on two separate data matrices for averaged values of soil parameters for the

same values of the distance and time elapsed after glacier retreat defined for three transects. Fitted function formulas are presented in the graphs

and TN contents in soil was recorded (Fig. 5). Apart from TOC and TN contents, TS content also follows a similar pattern. Sulphur is an essential nutrient for microorganisms, plants, and animals. In pristine regions with geological parent material categorised as S-poor due to little atmospheric $\mathrm{S}$ input and young soils, the bioavailability of S may limit ecosystem production and species succession (Schmalenberger and Noll 2010). We found that the TS content in the surface soil layer generally increased with time elapsed after glacier retreat and distance from the current glacier forehead; however, wide fluctuations were noticeable (Fig. 4). Moreover, in terms of distance intervals, the highest mean content of TS was recorded at 750-950 m from the current glacier forehead, compared to a lower mean content for the greatest distance interval, i.e. 1000$1150 \mathrm{~m}$ (Fig. 3). Similar observations were made by Prietzel et al. (2013) in foreland surface soil layers at the Damma Glacier in Switzerland, where the concentration of TS was at its lowest level in the fresh foreland material and its highest in mature soils, but generally was greater for 70- to 79-year-old than for 111- to 121year-old soils. In the foreland surface soil layer of the

Damma Glacier, the content of TS was positively correlated with TOC content (Prietzel et al. 2013). In the present study we also found significant positive correlations between TS and TOC contents. However, older soils are not always characterised by higher TS contents than younger soils. Similar relationships were also observed in the soils of the forelands of Franz Josef Glacier and Damma Glacier (Allison et al. 2007; Prietzel et al. 2013).

The variable rate of glacier retreat over time is certainly one of the important factors influencing the observed pattern of dependence between distance and soil properties. In terms of distance, this rate was considerably higher over the past several years than previously (Fig. 6). The results indicate that the contents of TOC and $\mathrm{TN}$ in soils developed in the foreland of the Irenebreen are, in general, a function of time and distance from the glacier forehead. Nevertheless, the accumulation of these elements does not fit a simple linear model in accordance with distance from the glacier forehead. The patterns of changes with distance are very characteristic and the increase in the contents of these elements is expressed by non-linear functions. These 
Fig. 6 The relatioship between the time elapsed after glacier retreat and the distance from the glacier forehead for particular transects

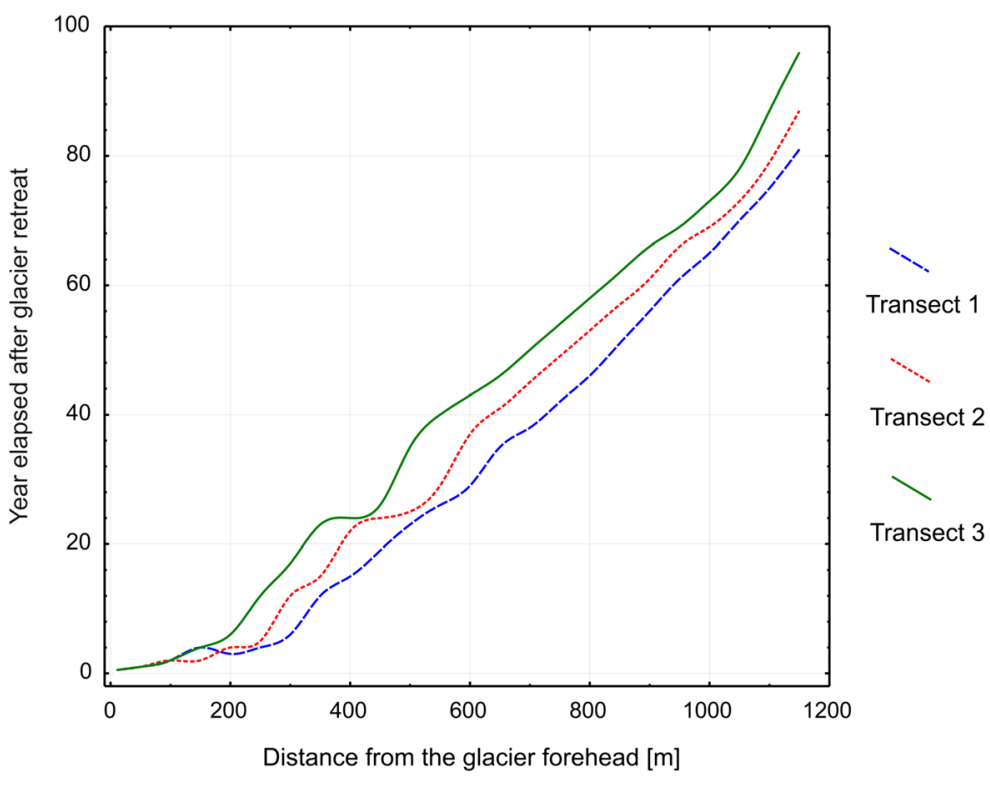

soil development measures are distance-related and fit power and exponential models for TOC and TN, respectively. Consequently, the accumulation of TOC and TN at distances such as the first $500 \mathrm{~m}$ from the current glacier forehead was lower than for the next $500 \mathrm{~m}$; this was also connected with a shorter period of soil development. Nevertheless, the models created in this study stand in contradiction to relationships observed in the Werenskioldbreen foreland (south-western part of Spitsbergen), where TOC and TN accumulation fits a logarithmic model and, in the fourth/fifth decade after deglaciation, it has reached a quasi-steady state over a time span of 80 years (Kabala and Zapart 2012). These differences might be due to the different methodology used by these authors, namely, the classical chronosequence method, which also resulted in a smaller number of samples being collected in the foreland of the Werenskioldbreen glacier. In addition, Kabala and Zapart (2012) included in their study soils located only on typical moraine till, whereas soils formed from outwash sands and gravels, glaciofluvial and limnic deposits were excluded from their study. We collected soil samples from various sites in the foreland (not only at sites located on typical moraine till) without exclusion of any sites and this is most likely the second reason for a different pattern of TOC and TN content increase along the transects in our study in comparison with the pattern obtained by Kabala and Zapart (2012). Furthermore, the geomorphological character of each foreland, connected with thawing ice cores and thus surface stability, may influence the contents of TOC and TN along the foreland. The absence or deeper occurrence of thawing ice cores results in a more stable foreland surface, enabling faster vegetation colonisation and greater accumulation of elements such as TOC and $\mathrm{TN}$. On the other hand, the general increasing trend in TN content found in the present study seems similar to that observed in the Midtre Lovénbreen foreland (Hodkinson et al. 2003), although the authors did not determine the best-fitting function for nitrogen content. The increase in the content of this element was relatively slow at first, but became more pronounced 60 years after glacier retreat. Different relationships were observed in the foreland of the Midtre Lovénbreen by Dong et al. (2016), where linear functions provided the best fit and TOC and TN contents increased steadily over a time span greater than 80 years after deglaciation. Consequently, our second hypothesis assuming that the relationship between time elapsed after glacier retreat and soil properties is close to being linear was confirmed only in the case of TN content, because the relationship between TOC content and time elapsed after glacier retreat was non-linear. Similarly, the above-mentioned hypothesis was not fully confirmed in the case of TS content, because the character of TS changes was linear with time elapsed after glacier retreat and also with the distance from the glacier forehead. The patterns and time trends of the surface soil layer TS status of young foreland-derived soils in cool, humid periglacial environments during initial stages of pedogenesis and 
vegetation succession were caused by the combined effects of mineral weathering, accumulation and progressive microbial turnover of soil organic matter, and type of vegetation succession (Prietzel et al. 2013). Since the parent material of soils in the foreland of Irenebreen is S-poor (Bjørnerud 2010), we supposed that organic matter and vegetation cover were the major factors affecting the increase in TS content along with soil development in the studied foreland. The wide variations in TS content with time and distance could be somehow explained by parent material heterogeneity, influence of atmospheric aerosols containing sulphates (Udisti et al. 2016) or volcanic eruptions (e.g. Icelandic volcanos) during which large volume of ashes containing sulphur are produced, transported into the atmosphere and spread widely (Kekonen et al. 2005). Nevertheless, an increasing trend in the TS content is still observable due to the large contribution of the accumulation of TS in the surface soil layer as a consequence of the establishment of vegetation.

The expected negative correlation of soil $\mathrm{pH}$ with distance and time factors as well as with spontaneous development of vegetation was also confirmed by our results, which is in line with our first and third hypothesis. The $\mathrm{pH}$ of fresh foreland glacial till is quite high, fluctuating around 8 . This is mainly due to the types of rocks representing the Hecla Hoek Formation and the mineralogical composition of glacial till, which includes a high proportion of calcium and magnesium carbonate (Chlebowski 1989). Since vegetation cover develops in forelands, organic acids from decaying plant debris cause a progressive decrease in soil $\mathrm{pH}$ (Fig. 5). In addition, the influence of summer precipitation and thawing of snow cover may also be responsible for leaching of carbonates from upper soil horizons leading to a decrease in soil $\mathrm{pH}$. The increase in $\mathrm{pH}$ with depth in the studied soil profiles located in the middle and especially at the furthest sites from the current position of the glacier forehead indicates the leaching of carbonates (Table S3). However, it is not possible to determine which factor (i.e. development of vegetation cover or leaching) plays a more important role in decreasing soil $\mathrm{pH}$ in the studied foreland. We also found that the decrease in soil $\mathrm{pH}$ is a linear function of time in the foreland soils of Irenebreen (Fig. 4). Similar trends in $\mathrm{pH}$ were also found for the soils of the Midtre Lovénbreen foreland (Dong et al. 2016). On the other hand, Kabala and Zapart (2012) found that $\mathrm{pH}$ decreased with time and became finally stabilised approximately 80 years after glacier retreat. He and Tang (2008) also observed that $\mathrm{pH}$ in surface soil horizons tended to change asymptotically with time and thus progressive decreases in soil $\mathrm{pH}$ slowed with soil development and finally stabilised. The same $\mathrm{pH}$ changes were found in the recessional forelands of the Herbert and Mendenhall Glaciers in south-eastern Alaska where, after an initial rapid rate of decline in $\mathrm{pH}$, changes become less rapid and finally stabilise (Crocker and Dickson 1957).

Although a linear function of $\mathrm{pH}$ decline proved to fit our data best, the increase in soil $\mathrm{pH}$ recorded at the last sampling sites may indicate that $\mathrm{pH}$ tends to stabilise in the Irenebreen foreland as well. Nevertheless, our second hypothesis assuming that the relationship between time elapsed after glacier retreat and soil $\mathrm{pH}$ is linear was confirmed; however, the results stand in contrast to the hypothesis that the relationship between distance and soil $\mathrm{pH}$ is non-linear in character.

Vegetation development in the glacier foreland

The increase in the number of species and their cover with distance from the glacier forehead indicates that vegetation gradually changes along the studied transect (Figs. 7 and 9). The colonisation order is as follows: first appear bryophytes, then vascular plants and lichens. However, in the case of lichens, the first recorded species were epilithic taxa which overgrow rocks uncovered by the retreating ice, while epigeic species occur last (Fig. 7). According to phytosociological research on the climax Minuartia biflora community (Wegrzyn and Wietrzyk 2015), which surrounds the Irenebreen foreland, a gradual transition of species composition, from the pioneer stage to near-climax vegetation communities, can be observed in the glacier foreland. According to a study carried out in the Midtre Lovénbreen and Austre Lovénbreen (Moreau et al. 2008), the increase found in the frequency and cover of Stereocaulon alpinum is an indicator of climax vegetation. In the Irenebreen foreland, S. alpinum starts to occur approximately $500 \mathrm{~m}$ from the current glacier forehead. This may suggest that the presence of this lichen is not related strictly to climax communities. S. alpinum, such as another species of terricolous lichen, Rostania ceranisca (dominant taxon in the Irenebreen foreland), is a host for cyanobacterial symbionts with the ability to bind atmospheric nitrogen. This feature increases the colonisation potential of these lichens (Sancho et al. 2011). 


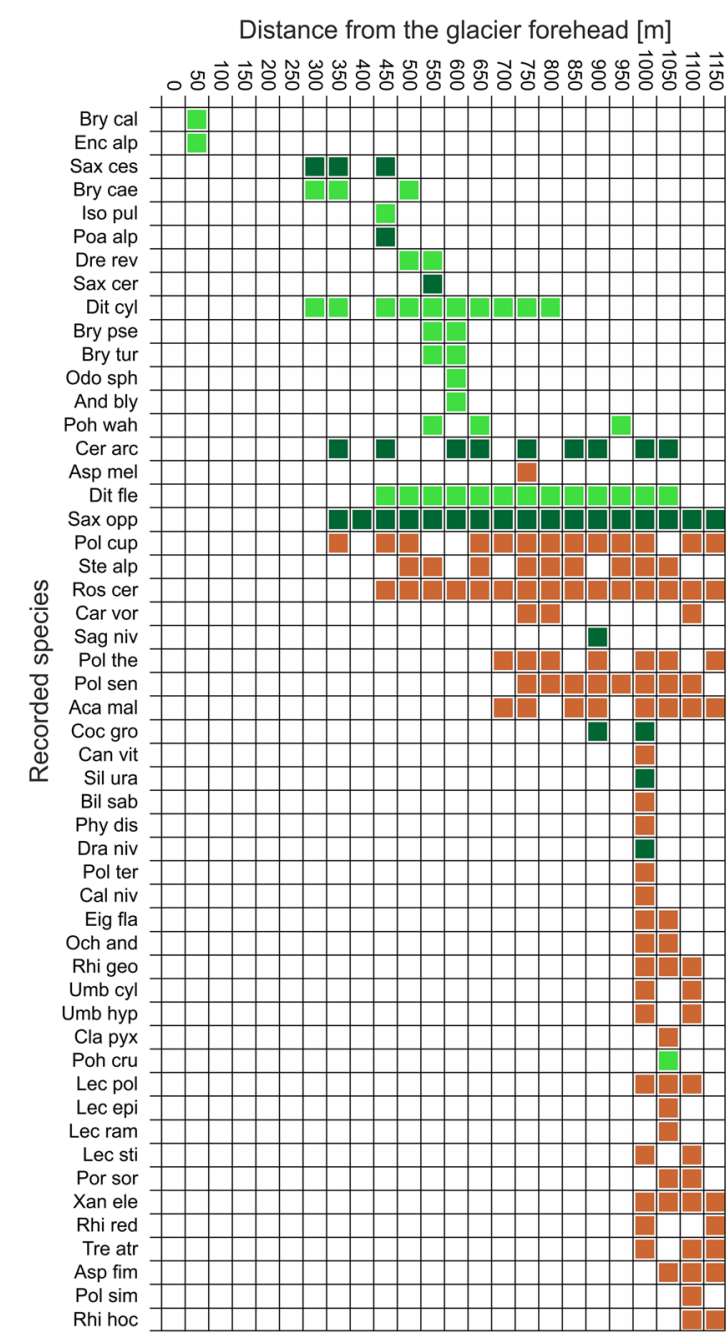

bryophytes

vascular plants

lichens

Aca mol - Acarospora molybdina; And bly - Andreaea blyttii; Asp fim - Aspicilia fimbriata; Asp mel - Aspicilia melanaspis; Bil sab - Bilimbia sabuletorum; Bry cae - Bryum caespiticium; Bry cal - Bryum calophyllum; Bry pse - Bryum pseudotriquetrum; Bry tur Bryum turgidum; Cal niv -Caloplaca nivalis; Can vit - Candelariella vitellina; Car vor Carbonea vorticosa; Cer arc - Cerastium arcticum; Cla pyx - Cladonia pyxidata; Coc gro Cochlearia groenlandica; Dit cyl - Ditrichum cylindricum; Dit fle - Ditrichum flexicaule; Dra Cochlearia groenlandica; Dit cyl - Ditrichum cylindricum; Dit fle - Ditrichum flexicaule; Dra
niv - Draba nivalis; Dre rev - Drepanocladus revolvens; Eig fla - Eiglera flavida; Enc alp Encalypta alpina; Iso pul - Isopterygiopsis pulchella; Lec epi - Lecanora epibryon; Lec pol Lecanora polytropa; Lec ram - Lecidea ramulosa; Lec sti - Lecidella stigmatea; Och and Ochrolechia androgyna; Odo sph - Odontoschisma sphagni; Phy dis - Physconia distorta; Poa alp - Poa alpina; Poh cru - Pohlia cruda; Poh wah - Pohlia wahlenbergii; Pol cup Polyblastia cupularis; Pol sen - Polyblastia sendtneri; Pol ter - Polyblastia terrestris; Pol the - Polyblastia theleodes; Pol sim - Polysporina simplex; Por sor - Porpidia soredizodes; Rhi - Polyblastia theleodes, Polsin-Polysporina simplex, Por sor - Porpida soredizodes; Rhi geo - Rhizocarpon geographicum, Rhi hoc - Rhizocarpon hochstetteri; Rhi red Rhizocarpon reductum, Ros cer - Rostaniaceranisca; Sag niv - Sagina nivalis, Sax ces Saxifragacespitosa; Sax cer-Saxifragacenua; Sax opp-Saxifaga opposilfolla; Sil ura Silene uralensis; Ste alp - Stereocaulon alpinum; Tre atr - Tremolecia atrata; Umb cyl Umbilicaria cylindrica; Umb hyp - Umbilicaria hyperborean; Xan ele - Xanthoria elegans

Fig. 7 The seriation diagram using unconstrained algorithm of species presence/absence in the examined plots combined for three transects

In the majority of Earth's ecosystems, vegetation cover is considered to be a response to the gradient of soil parameters; however, in the Arctic region, in areas surrounded by glaciers, an important factor influencing vegetation cover is also the microclimatic impact of a glacier's presence. According to multiple regression analysis, except for soil properties such as $\mathrm{pH}$, TOC and $\mathrm{TN}$, vegetation cover depends on distance from the glacier forehead. This result partly confirmed our fourth hypothesis assuming that the development of vegetation cover is dependent mainly on the distance from the glacier forehead (Fig. 9). With regard to statistical significance, distance was the second significant factor (after soil $\mathrm{pH}$ ) affecting the vegetation cover. Nevertheless, this model explained only $38.4 \%$ of the variability of vegetation cover. This indicates that further research focused on factors influencing the development of vegetation cover in a glacier foreland such as nutrients available to plants, soil humidity, soil texture, and presence of biological soil crusts (BSCs) is needed. Concerning the occurrence of particular species, the analysis of CCA along with forward selection procedure shows that distance from the glacier forehead and TOC content in the soil affect species distribution the most (Fig. 9). Nevertheless, regarding TOC content, it is mainly related to lichens, such as $C$. pyxidata, L. epibryon, L. ramulosa, and O. androgyna (Fig. 9). The occurence of these species is caused by the presence of plant debris and BSCs, which provide them with the substrate to grow on (Smith et al. 2009). Due to this fact, it seems that the positive relationship between the mentioned species and TOC content is indirect and connected with readily available plant debris and BSCs, which directly result in high TOC content in the soil. The majority of epigeic lichens dominate in the older part of the studied foreland (Fig. 7). This indicates the highest level of species diversity in the areas where ice disappeared early, the species had enough time to colonise the substrate, and where the influence of dead-ice thawing and glacier-affected microclimate is lower. A great abundance of lichens in the parts of the foreland exposed earliest was also observed in the Midtre Lovénbreen (Moreau et al. 2008). In studies conducted in the foreland of the Werenskioldbreen, Tishkov (1986) emphasised the importance of socalled micro-depressions, which accelerate the process of primary succession due to optimal snow accumulation conditions. Apart from that, various geomorphological processes transform glacial till in forelands. Among them, the most important geomorphological processes are related to the melting of ice-cores and activity of proglacial rivers. Many studies (e.g. Borysiak et al. 2015; Laffly and Mercier 2002; Mercier and Laffly 
Fig. 8 The relationship between vegetation cover and the distance from the glacier forehead averaged for three transects

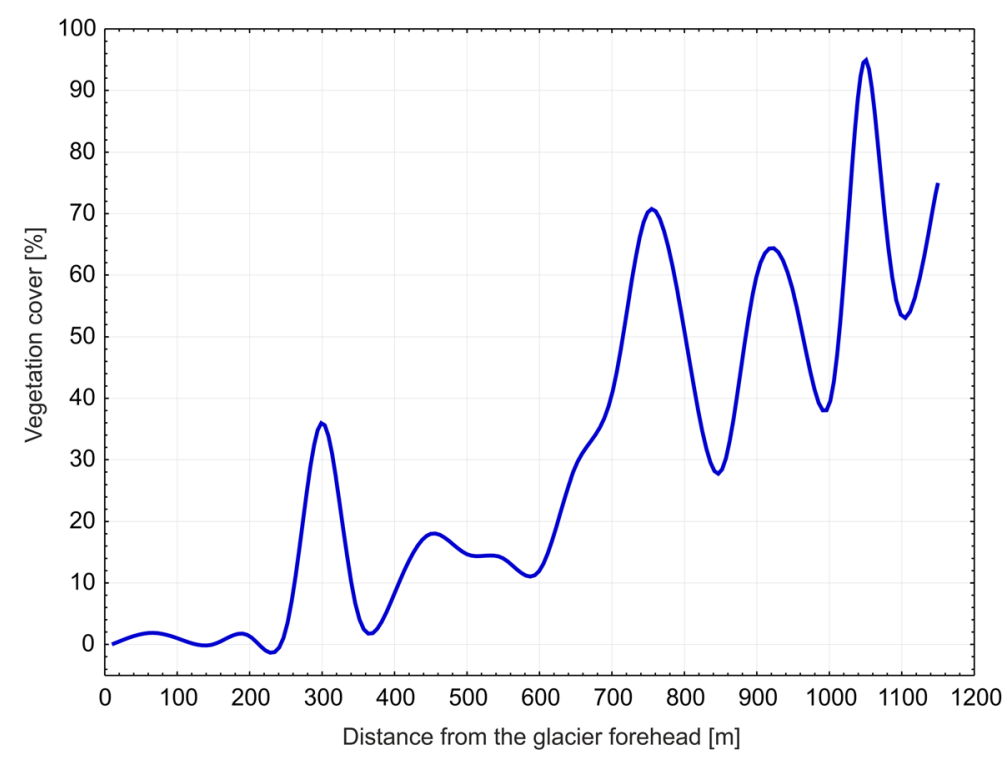

2005; Moreau et al. 2008; Östrem 1959; Prach and Rachlewicz 2012;) indicate that the above-mentioned processes are the main and most influential in the formation of lowlands and mounds in glacier forelands, and thus appear to exert an important impact on vegetation development. In contrast to epigeic lichens, bryophytes dominate in the younger part of the studied foreland (Fig. 7). These include mainly minerotrophic species, which inhabit moist areas (Atherton et al. 2010; Walker et al. 2001) and seem to tolerate the erosional activity of proglacial rivers which occurs periodically in the areas located near the current glacier forehead (Fig. 7). Ditrichum cylindricum, in particular, prefers a distinctly wet habitat that undergoes periodic flooding (Walker et al. 2001). This is confirmed by CCA analysis, which shows that the majority of bryophytes are associated with substrates with lesser content of TOC, TN, and TS, but higher soil pH (Fig. 9). Bryophyte species recorded in the older part of foreland were associated with local micro-depressions, which provide higher moisture content in the substrate in comparison with surrounding mounds (Fig. S1). In the case of vascular plants, those whose presence is
Fig. 9 Canonical correspondence analysis ordination diagram showing relathionship between species (species abbreviations are explained in Fig. 7), soil variables (TOC, TN, TS, pH), distance from the current glacier forehead (distance) and time elapsed after glacier retreat (time). The red arrows and underlined variables mark the statistically significant factors. The variance explained by the first canonical axis reaches $45 \%$ whereas by all canonical axes $79 \%$

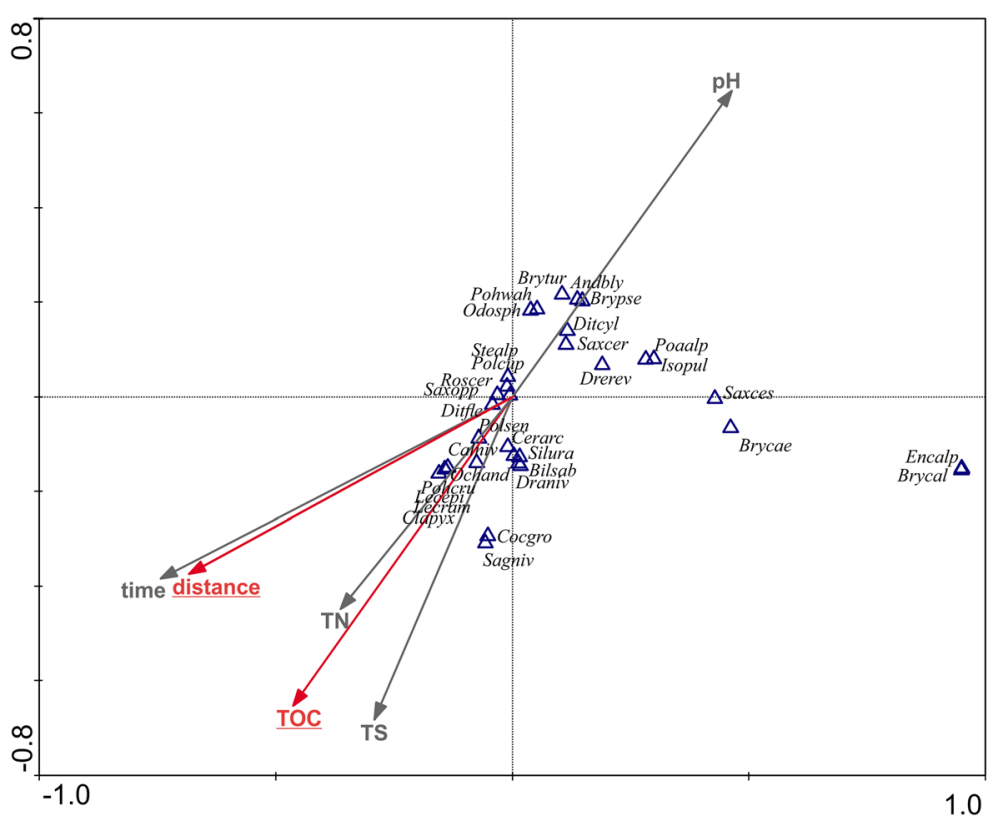


connected to the microclimatic influence of glacier and ice-cores, occur first in the colonisation process and are present only in the younger part of the foreland, e.g.: S. cesposita, S. cernua and P. alpina (Figs. 7 and 9). Conversely, $S$. oppositifolia and C. arcticum, which appear as the first vascular plant species, dominate towards the end of the foreland and show a greater tolerance for habitat conditions that change along the foreland (Fig. 7). The important role of $S$. oppositifolia and its domination in the succession process was also noted in the forelands of other glaciers in the northern (Hodkinson et al. 2003; Moreau et al. 2005, 2009; Tishkov 1986), southern (Pirożnikow and Górniak 1992; Wojtuń et al. 2008), north-eastern (Yoshitake et al. 2010), and central (Prach and Rachlewicz 2012) parts of the Svalbard Archipelago.

\section{Conclusions}

This paper provides a novel approach to studies concerning soil development and plant succession in a glacier foreland. The applied methodology provides nearcontinuous information on the soil development and vegetation succession spanning one century. Our results show that the contents of TOC and TN in soils developed in the Irenebreen foreland, rather than fitting a simple linear model in terms of their variation with distance from the glacier forehead, fit power and exponential models, respectively. The gradual colonisation of the foreland by cryptogams and vascular plants also affects soil $\mathrm{pH}$, which decreases with time according to a linear function; however the additional impact of soil leaching related to summer precipitation and the thawing of snow cover cannot be entirely excluded. Similarly, the content of TS in soils appears to be affected by the formation of vegetation cover and accumulation of organic matter; however, its wide variations with time and distance from the current glacier forehead may also be explained by the heterogeneity of parent material and/or the influence of atmospheric aerosols and/or volcanic deposits. Bryophytes and vascular plants dominate in the younger part of the studied foreland, whereas epigeic lichens prevail in the older part. This indicates that epigeic lichens need more time than bryophytes and vascular plants to colonise a glacier foreland. The study showed that a particular species distribution is associated with the distance from the glacier forehead and TOC content in soil. Nevertheless, concerning the overall vegetation cover, apart from the above-mentioned factors, $\mathrm{pH}$ and $\mathrm{TN}$ seem to also impact the development of vegetation cover.

Acknowledgements We are grateful to Associate Professor Ireneusz Sobota, the Station Leader of Nicolaus Copernicus University Polar Station in Kaffiøyra for the opportunity to stay at the research station. We wish to thank Doctor Beata CykowskaMarzencka (Institute of Botany, Polish Academy of Sciences) for her help in bryophytes identification. We are also grateful to anonymous reviewers for their suggestions and remarks on our manuscript. The contribution made by Michał Wegrzyn in 2012 was financially supported by a statutory fund from the Institute of Botany, Jagiellonian University. The contribution made by Paulina Wietrzyk received financial support from the statutory fund of the Institute of Botany of the Jagiellonian University (K/DSC/004623).

Open Access This article is distributed under the terms of the Creative Commons Attribution 4.0 International License (http:// creativecommons.org/licenses/by/4.0/), which permits unrestricted use, distribution, and reproduction in any medium, provided you give appropriate credit to the original author(s) and the source, provide a link to the Creative Commons license, and indicate if changes were made.

\section{References}

Alexander EB, Burt R (1996) Soil development on moraines of Mendenhall glacier, Southeast Alaska. 1. The moraines and soil morphology. Geoderma 72:1-17. https://doi.org/10.1016 /0016-7061(96)00021-3

Allison VJ, Condron LM, Peltzer DA, Richardson SJ, Turner BL (2007) Changes in enzyme activities and soil microbial community composition along carbon and nutrient gradients at the Franz Josef chronosequence, New Zealand. Soil Biol Biochem 39:1770-1781. https://doi.org/10.1016/j.soilbio.2007.02.006

Arndt DS, Baringer MO, Johnson MR, Diamond HJ, Fogt RL, Levy JM, Thorne PW, Vincent LA, Watkins AB, Willett KM (2010) State of the climate in 2009. Bull Am Meteorol Soc 91(7):S1-S223. https://doi.org/10.1175/BAMS-91-7StateoftheClimate

Atherton I, Bosanquet S, Lawley M (2010) Mosses and liverworts of Britain and Ireland: a field guide. British Bryological Society, London

Bjørnerud MG (2010) Stratigraphic record of Neoproterozoic ice sheet collapse: the Kapp Lyell diamictite sequence, SW Spitsbergen, Svalbard. Geol Mag 147(3):380-390. https://doi.org/10.1017/S0016756809990690

Błaszczyk M, Jania JA, Hagen JO (2009) Tidewater glaciers of Svalbard: recent changes and estimates of calving fluxes. Pol Polar Res 30(2):85-142

Borysiak J, Grześ M, Pulina M, Szpikowska G (2015) Hydrogeochemical and biogeochemical processes in Kaffiøyra River catchments (Spitsbergen, Norway). Quaest Geographicae 34(1):111-124. https://doi.org/10.1515 /quageo-2015-0010

Brady NC, Weil RR (2004) The nature and properties of soils. Pearson Education Inc, Delhi 
Brodo IM, Sharnoff SD, Sharnoff S (2001) Lichens of North America. Yale University Press, New Haven

Brower JC, Kile KM (1988) Sedation of an original data matrix as applied to paleoecology. Lethaia 21:79-93. https://doi. org/10.1111/j.1502-3931.1988.tb01756.x

Burga CA, Krüsi B, Egli M, Wernli M, Elsener S, Ziefle M, Fischer T, Mavris C (2010) Plant succession and soil development on the foreland of the Morteratsch glacier (Pontresina, Switzerland): straight forward or chaotic? Flora Morphol Distrib Funct Ecol Plants 205:561-576. https://doi. org/10.1016/j.flora.2009.10.001

Chlebowski R (1989) Petrographie and mineralogical characteristics of rocks of the Hecla Hoek formation in the area of the south Bellsund coast, West Spitsbergen Wyprawy Geograficzne na Spitsbergen, pp 51-59

Crocker RL, Dickson BA (1957) Soil development on the recessional moraines of the Herbert and Mendenhall glaciers, south-eastern Alaska. Br Ecol Soc 45:169-185. https://doi. org/10.2307/2257083

Dai LM, Wu G, Zhao JZ, Kong HM, Shao GF, Deng HB (2002) Carbon cycling of alpine tundra ecosystems on Changbai Mountain and its comparison with Arctic tundra. Sci China Ser D Earth Sci 45:903-910. https://doi.org/10.1360/02yd9089

Dong K, Tripathi B, Moroenyane I, Kim W, Li N, Chu H, Adams J (2016) Soil fungal community development in a high Arctic glacier foreland follows a directional replacement model, with a mid-successional diversity maximum. Sci Rep 6: 26360. https://doi.org/10.1038/srep26360

Dümig A, Smittenberg R, Kögel-Knabner I (2011) Concurrent evolution of organic and mineral components during initial soil development after retreat of the Damma glacier, Switzerland. Geoderma 163:83-94. https://doi.org/10.1016 /j.geoderma.2011.04.006

Elberling B, Jakobsen BH, Berg P, Sondergaard J, Sigsgaard C (2004) Influence of vegetation, temperature, and water content on soil carbon distribution and mineralization in four high Arctic soils. Arct Antarct Alp Res 36:528-538. https:// doi.org/10.1657/1523-0430(2004)036[0528: IOVTAW]2.0.CO;2

Grieve IC (2000) Effects of human disturbance and cryoturbation on soil iron and organic matter distributions and on carbon storage at high elevations in the Cairngorm Mountains, Scotland. Geoderma 95:1-14. https://doi.org/10.1016 /S0016-7061(99)00060-9

Hammer Ø, Harper DAT, Ryan PD (2001) PAST-palaeontological statistics, ver. 1.89. Palaeontol Electron 4(1):1-9

Hansen J, Sato M, Ruedy R (2012) Perception of climate change. Proc Natl Acad Sci 109:E2415-E2423. https://doi. org/10.1073/pnas.1205276109

He L, Tang Y (2008) Soil development along primary succession sequences on moraines of Hailuogou glacier, Gongga Mountain, Sichuan, China. Catena 72:259-269. https://doi. org/10.1016/j.catena.2007.05.010

Hodkinson ID, Coulson SJ, Webb NR (2003) Community assembly along proglacial chronosequences in the high Arctic: vegetation and soil development in north-West Svalbard. J Ecol 91:651-663. https://doi.org/10.1046/j.13652745.2003.00786.x

IPCC (2007) Climate change 2007: the physical science basis. Contribution of working group I to the fourth assessment report of the intergovernmental panel on climate change. Summary for Policymakers. IPCC, Geneva

IPCC (2014) Climate change 2014: synthesis report. Contribution of working groups I, II and III to the Fifth Assessment Report of the Intergovernmental Panel on Climate Change. IPCC, Geneva

Jacobson GL, Birks HJB (1980) Soil development on recent end moraines of the Klutlan glacier, Yukon territory, Canada. Quat Res 14:87-100. https://doi.org/10.1016/0033-5894(80 )90008-3

James TD, Murray T, Barrand NE, Sykes HJ, Fox AJ, King MA (2012) Observations of enhanced thinning in the upper reaches of Svalbard glaciers. Cryosphere 6:1369-1381. https://doi.org/10.5194/tc-6-1369-2012

Kabala C, Zapart J (2012) Initial soil development and carbon accumulation on moraines of the rapidly retreating Werenskiold glacier, SW Spitsbergen, Svalbard archipelago. Geoderma 175-176:9-20. https://doi.org/10.1016/j. geoderma.2012.01.025

Kekonen T, Moore J, Perämäki P, Martma T (2005) The Icelandic Laki volcanic tephra layer in the Lomonosovfonna ice core, Svalbard. Polar Res 24(1-2):33-40. https://doi.org/10.3402 /polar.v24i1.6251

Kohler J, James TD, Murray T, Nuth C, Brandt O, Barrand NE, Aas HF, Luckman A (2007) Acceleration in thinning rate on western Svalbard glaciers. Geophys Res Lett 34:L18502. https://doi.org/10.1029/2007GL030681

Laffly D, Mercier D (2002) Global change and paraglacial morphodynamic modification in Svalbard. Int $\mathrm{J}$ Remote Sens 23:4743-4760. https://doi.org/10.1080 /01431160110113872

Legendre P, Legendre L (1998) Numerical Ecology. Elsevier, Amsterdam

Mavris C, Egli M, Plötze M, Blum JD, Mirabella A, Giaccai D, Haeberli W (2010) Initial stages of weathering and soil formation in the Morteratsch proglacial area (upper Engadine, Switzerland). Geoderma 155:359-371. https://doi.org/10.1016/j.geoderma.2009.12.019

Mercier D, Laffly D (2005) Actual paraglacial progradation of the coastal zone in the Kongsfjorden area, West Spitsbergen (Svalbard). In: Harris C, Murton J (eds) Cryospheric Systems: Glaciers and Permafrost. Geological Society, London, pp 111-117

Moreau M, Laffly D, Joly D, Brossard T (2005) Analysis of plant colonization on an arctic moraine since the end of the Little Ice Age using remotely sensed data and a Bayesian approach. Remote Sens Environ 99:244-253. https://doi.org/10.1016/j. rse.2005.03.017

Moreau M, Mercier D, Laffly D, Roussel E (2008) Impacts of recent paraglacial dynamics on plant colonization: a case study on Midtre Lovénbreen foreland, Spitsbergen $\left(79^{\circ} \mathrm{N}\right)$. Geomorphology 95:48-60. https://doi.org/10.1016/j. geomorph.2006.07.031

Moreau M, Laffly D, Brossard T (2009) Recent spatial development of Svalbard strandflat vegetation over a period of 31 years. Polar Res 28(3):364-375. https://doi.org/10.1111 j.1751-8369.2009.00119.x

Nakatsubo T, Bekku YS, Uchida M, Muraoka H, Kume A, Ohtsuka T, Masuzawa T, Kanda H, Koizumi H (2005) Ecosystem development and carbon cycle on a glacier foreland in the high Arctic, Ny-Alesund, Svalbard. J Plant Res 118(3):173-179. https://doi.org/10.1007/s10265-005-0211-9 
Noll M, Wellinger M (2008) Changes of the soil ecosystem along a receding glacier: testing the correlation between environmental factors and bacterial community structure. Soil Biol Biochem 40(10):2611-2619. https://doi.org/10.1016/j. soilbio.2008.07.012

Nuth C, Kohler J, König M, von Deschwanden A, Hagen JO, Kääb A, Moholdt G, Pettersson R (2013) Decadal changes from a multi-temporal glacier inventory of Svalbard. Cryosphere 7: 1603-1621. https://doi.org/10.5194/tc-7-1603-2013

Oechel WC, Vourlitis GL (1994) The effects of climate charge on landatmosphere feedbacks in Arctic tundra regions. Trends Ecol Evol 9(9):324-329. https://doi.org/10.1016/0169-5347(94)90152-X

Orange A, James PW, White FJ (2001) Microchemical methods for the identification of lichens. British Lichen Society, London

Östrem G (1959) Ice melting under a thin layer of moraine, and the existence of ice cores in moraine ridges. Geogr Ann 41(4): 228-230. https://doi.org/10.1080/20014422.1959.11907953

Osyczka P, Wegrzyn M. (2008) Lichens on lignum in the coastal regions of western Spitsbergen (Svalbard). Biologia 63(6): 1069-1072. https://doi.org/10.2478/s11756-008-0158-0

Pirożnikow E, Górniak A (1992) Changes in the characteristics of the soil and vegetation during the primary succession in the marginal zone of the Werenskiold glacier, Spitsbergen. Pol Polar Res 13(1):19-29

Prach K, Rachlewicz G (2012) Succession of vascular plants in front of retreating glaciers in Central Spitsbergen. Pol Polar Res 33(4):319-328. https://doi.org/10.2478/v10183-012-0022-3

Prietzel J, Wu Y, Dümig A, Zhou J, Klysubun W (2013) Soil sulphur speciation in two glacier forefield soil chronosequences assessed by S K-edge XANES spectroscopy. Eur J Soil Sci 64(2):260-272. https://doi.org/10.1111/ejss.12032

Przybylak R, Araźny A (2006) Climatic conditions of the north western part of Oscar II land (Spitsbergen) in the period between 1975 and 2000. Pol Polar Res 27(2):133-152

Rønning OI (1996) The flora of Svalbard. Norwegian Polar Institute, Tromso

Sancho LG, Palacios D, Green ATG, Vivas M, Pintado A (2011) Extreme high lichen growth rates detected in recently deglaciated areas in Tierra del Fuego. Polar Biol 34:813-822. https://doi.org/10.1007/s00300-010-0935-4

Schmalenberger A, Noll M (2010) Shifts in desulfonating bacterial communities along a soil chronosequence in the forefield of a receding glacier. FEMS Microbiol Ecol 71(2):208-217. https://doi.org/10.1111/j.1574-6941.2009.00799.x

Smith CW, Aptroot A, Coppins BJ, Fletcher A, Gilbert OL, James PW, Wolseley PA (2009) The lichens of great Britain and Ireland. British Lichen Society, London

Sobota I (2011) Snow accumulation, melt, mass loss, and the nearsurface ice temperature structure of Irenebreen, Svalbard. Polar Sci 5(3):327-336. https://doi.org/10.1016/j.polar.2011.06.003

Sobota I (2014) Changes in dynamics and runoff from the high Arctic glacial catchment of Waldemarbreen, Svalbard. Geomorphology 212:16-27. https://doi.org/10.1016/j.geomorph.2013.04.001

Sobota I, Lankauf KR (2010) Recession of Kaffiøyra region glaciers, Oscar II land, Svalbard. Bull Geogr Phys Geogr Ser 3:27-45. https://doi.org/10.2478/232

Sobota I, Nowak M, Weckwerth P (2016) Long-term changes of glaciers in North-Western Spitsbergen. Glob Planet Chang 144:182-197. https://doi.org/10.1016/j.gloplacha.2016.07.006

Tan KH (1995) Soil sampling, preparation, and analysis. Marcel Dekker Inc, New York
Ter Braak CJF, Šmilauer P (2002) CANOCO 4.5 reference manual and CanoDraw for Windows user's guide: software for canonical community ordination. Ithaca: Microcomputer Power, New York

Thomson JW (1984) American Arctic lichens I: the macrolichens. Columbia University Press, New York

Thomson JW (1997) American Arctic lichens II: the microlichens. University of Wisconsin Press, Madison

Tishkov AA (1986) Primary succession in arctic tundra on the west coast of Spitsbergen (Svalbard). Polar Geogr Geol 10: 148-156. https://doi.org/10.1080/10889378609377282

Udisti R, Bazzano A, Becagli S, Bolzacchini E, Caiazzo L, Cappelletti D, Ferrero L, Frosini D, Giardi F, Grotti M, Lupi A, Malandrino M, Mazzola M, Moroni B, Severi M, Traversi R, Viola A, Vitale V (2016) Sulfate source apportionment in the Ny-Ålesund (Svalbard Islands) Arctic aerosol. Rendiconti Lincei 27:85-94. https://doi.org/10.1007/s12210-016-0517-7

Vilmundardóttir OK, Gísladóttir G, Lal R (2015) Soil carbon accretion along an age chronosequence formed by the retreat of the Skaftafellsjökull glacier, SE-Iceland. Geomorphology 228: 124-133. https://doi.org/10.1016/j.geomorph.2014.08.030

Walker LR, Del Moral R (2003) Primary succession and ecosystem rehabilitation. Cambridge University Press, Cambridge

Walker DA, Bockheim JG, Chapin FS III, Eugster W, Nelson FE, Ping CL (2001) Calcium-rich tundra, wildlife, and the "mammoth steppe". Quat Sci Rev 20:149-163. https://doi. org/10.1016/S0277-3791(00)00126-8

Wegrzyn M, Wietrzyk P (2015) Phytosociology of snowbed and exposed ridge vegetation of Svalbard. Polar Biol 38(11): 1905-1917. https://doi.org/10.1007/s00300-015-1751-7

Wietrzyk P, Węgrzyn M, Lisowska M (2016) Vegetation diversity and selected abiotic factors influencing the primary succession process on the foreland of Gåsbreen, Svalbard. Pol Polar Res 37(4):493-509. https://doi.org/10.1515/popore-2016-0026

Wietrzyk P, Wegrzyn M, Lisowska M (2017) Lichen diversity on glacier moraines in Svalbard. Cryptogam Mycol 38(1):6780. https://doi.org/10.7872/crym/v38.iss1.2017.67

Wojtuń B, Matuła J, Pereyma J (2008) Plant and lichen colonizations on the Werenskiöld glacier forefield in West Spitsbergen. In: Kowalska A, Latocha A, Maszałek H, Pereyma J (eds) Środowisko przyrodnicze obszarów polarnych. Wydział Nauk o Ziemi i Kształtowania Środowiska, GAJT, Wrocław, pp 228-236

Yoshitake S, Uchida M, Koizumi H, Nakatsubo T (2007) Carbon and nitrogen limitation of soil microbial respiration in a high Arctic successional glacier foreland near Ny-Ålesund, Svalbard. Polar Res 26:22-30. https://doi.org/10.1111 /j.1751-8369.2007.00001.x

Yoshitake S, Uchida M, Koizumi H, Kanda H, Nakatsubo T (2010) Production of biological soil crusts in the early stage of primary succession on a high Arctic glacier foreland. New Phytol 186: 451-460. https://doi.org/10.1111/j.1469-8137.2010.03180.x

Yoshitake S, Uchida M, Ohtsuka T, Kanda H, Koizumi H, Nakatsubo T (2011) Vegetation development and carbon storage on a glacier foreland in the high Arctic, NyÅlesund, Svalbard. Polar Sci 5(3):391-397. https://doi. org/10.1016/j.polar.2011.03.002

Zemp M, Paul F, Hoelzle M, Haeberlie W (2008) Glacier fluctuations in the European Alps, 1850-2000: an overview and spatio-temporal analysis of available data. In: Orlove B, Wiegandt E, Luckman BH (eds) The darkening peaks: Glaciar retreat, science and society. University of California Press, Berkeley, pp 152-167 